\title{
YOUNG PEOPLE IN THE EUROPEAN UNION LABOUR MARKET
}

\author{
Ewa Rollnik-Sadowska \\ $\mathrm{PhD}$, assistant professor, Bialystok University of Technology, \\ Faculty of Management, Bialystok, Poland, \\ email: e.rollnik@pb.edu.pl,phone:+48660759656
}

\begin{abstract}
In an era of aging of the European Union population, it is crucial to take care of human resources in various spheres of their life. The potential of young people is particularly important, as their economic activity creates the basis of maintaining the European welfare state model. However, the labour market situation of young people is difficult. Moreover, the phenomena, which have recently attracted increasing attention, are remaining for young people without employment, education or training (NEET). The occurrence of NEET's resources is harmful at micro level - due to pauperization of European households as well as for the whole economy due to insufficient usage of human resources. The paper aim is to compare how the situation of young people differs in the European Union labour markets.

The paper was based on both the desk-research of literature as well as the analysis of selected economic indicators of young people (aged 15-29 years). The indicator analysis was made through the usage of cluster analysis (Ward's method and k-means method). The data was gathered from the databases of Eurostat. The selected indicators determine the labour market situation of young people in the EU countries and they are derived from two years - 2006 and 2014.

Ward's and $k$-means methods allowed for dividing the EU countries into three groups. It occurred that the groups in 2006 have a completely different composition of countries than in 2014, which was mainly determined by crisis influences on the labour markets as well as directions of conducted reforms. Additionally, the k-means method allowed for comparison of selected groups on the basis of chosen variables and determination of countries with the best and the worst situation of young people.
\end{abstract}

Keywords: young people, labour market indicators, labour market policy, educational policy, NEET, European Union, Ward's method, k-means method.

JEL code: $J 2, J 6, J 8$

\section{Introduction}

The European population is continually subject to aging. The historical shape of its age pyramid has moved away from a triangle (associated with an expanding population) and has been reshaped, with a smaller proportion of children and young people and an increased share of elderly persons (Eurostat, 2015).

In such a demographic situation, maintaining European welfare systems, pension schemes and public healthcare systems, while the overall demand for such services is likely to increase, due to the rising number of elderly 
people, became a significant challenge. As such, policymakers are concerned about how to ensure the long-term sustainability of public finances in the face of a declining share of economically active people. The reasonable policy toward activation of young generations (together with family policy) can be treated as the priority of European cohesion orientation.

Such a policy is crucial, as the labour market situation of young people in the $\mathrm{EU}$ is much worse than in the entire generation. Moreover, the phenomena, which have recently attracted increasing attention, are remaining for young people without employment, education or training (NEET). Eurostat calculates that in 2014 the NEET rate of EU-28 reached $15.4 \%$. The occurrence of NEET's resources is harmful at micro level - due to the pauperization of European households as well as for the whole economy due to the insufficient usage of human resources.

The paper aims to compare how the situation of young people differs in the European Union labour markets.

The following tasks were set to accomplish the aim:

1. identifying of the indicators describing labour market situation of young people,

2. comparing of the labour market situation of young people among the EU countries in 2006 (before the economic crisis) and in 2014 (when labour markets were already under the effects of the crisis),

3. clustering of the European Union countries with respect to selected young people's labour market indicators,

4. elaborating of conclusions concerning the conducted analysis of the EU countries.

The main thesis of the paper is that the labour market situation of young people in the European Union is significantly diversified.

The paper was based on both the desk-research of literature as well as the analysis of selected economic indicators of young people (aged 1529 years) through usage of cluster analysis (Ward's and k-means methods). The data was gathered from the databases of Eurostat. The indicators were selected, which determined the situation of young people in the EU countries in two years - 2006 and 2014. The first year presented the period before the economic crisis, whereas in the 2014 the crisis has already fully affected European Union labour markets. 


\section{The main tendencies in professional activity of young people in the $\mathrm{EU}$}

The generation of people aged 15-29 in the EU is characterised by worse labour market indicators than their older counterparts. It concerns both a lower employment rate and a higher unemployment rate. The Eurostat data show that in 2014 the employment rate for the EU-28 countries reached $69.2 \%$ and the youth employment rate $-46.4 \%$; at the same time the unemployment rate for the EU-28 population in total reached $10.2 \%$ and for young people aged 15-29-17.3\%

Employment and education are intrinsically linked (EESC, 2011). The labour market situation of young people is determined not only by the potential of labour demand and the number of vacancies but also by the abilities of the education system in terms of providing graduates with the skills needed in the labour market.

Out of negative tendencies in professional activity of young people there should be determined early school leaving (ESL). It should also be noted that in most countries ESL is more prominent in vocational education training (VET) (European Commission).

As early school leaving is more frequent among young people from disadvantaged backgrounds, among people with migrant background and ethnic minorities such as Roma, and among boys, these should be key target groups for policy interventions. One of the objectives of the Europe 2020 strategy is to bring down the share of early school leavers to below $10 \%$ by 2020 .

In the current conjecture, the integration of youths in the society can no longer follow the traditional and linear path and model (as a succession of steps from school to job), and hence is replaced by diversified and individualised trajectories from school to job. Thus, traditional approaches regarding the analysis of youths' vulnerable position in the labour market are no longer efficient, as many of these transitions are not highlighted by the conventional indicators of the labour force market.

Therefore, researchers, national and international authorities began to use alternative concepts and indicators for characterising and analysing the situation of the youths in the labour market. For individuals aged between 15 and 29 years and those who, irrespective of their educational level, are not employed or in educational or vocational training and hence exposed to a higher risk of social and labour market exclusion, the NEET concept (not in employment, education or training) was coined (Bălan, 2015). 
The term NEET has come into the policy debate in recent years due to the disproportionate impact of the recession on young people (under 30 years old).

Unlike for unemployment or employment, there is no international standard for the definition of NEETs (Elder, 2015).

Eurostat, the ILO and certain other organizations have adopted the following definition of the NEET rate: the percentage of the population of a given age group and sex who is not employed and not involved in further education or training (Elder, 2015).

$$
\text { NEET rate }(\%)=\frac{\text { unemployed non-students }+ \text { inactive non-students }}{\text { youth population }} \times 100
$$

The numerator of the above indicator refers to persons meeting two conditions: (1) they are not employed (i.e. are unemployed or inactive), and (2) they have not received any education or training in the four weeks preceding the survey. The denominator, according to Eurostat, is the total population of the same age and sex group, excluding respondents who have not answered the question "Participation in regular education and training".

Current literature frequently simplifies the measurement of NEETs to unemployed + inactive non-students, ignoring the fact that some unemployed persons are also students and should thus be excluded from the calculation.

The NEET's rate can be treated as an important indicator describing the level of social exclusion, as the association of NEETs to marginalization offers the best "fit" among the numerous interpretations (Elder, 2015).

Youths' unemployment, the 'NEET' status, as well as the circumstances in which youths are forced to give up searching for a job, or forced to work in inadequate conditions have a strong impact on the economy of a society, on the families of these youths, and on their personal and professional development as well as on the society at large (Bălan, 2015).

Bynner and Parsons (2002) have identified in their developed studies a series of risk factors in becoming a NEET in Great Britain: the socioeconomic fund of the family, parental education, the interest of parents in child's education, the area of residence and the educational level for children. 
Eurofound determined the following risk factors of becoming a NEET in the EU (Eurofund, 2015):

- $\quad$ education - young people with a low level of education are 3 times more likely to become a NEET compared to others ${ }^{1}$.

- immigration - young people with immigration background are $70 \%$ more likely to become a NEET compared to nationals,

- disability - those declaring disability are $40 \%$ more likely of becoming a NEET compared to others,

- $\quad$ divorce - divorce of parents extends the possibility to become a NEET by $30 \%$,

- unemployment - having parents who have experienced unemployment increases the probability of being a NEET by $17 \%$,

- household income - young people with the low income in the household are more likely to become a NEET than others,

- location - living in remote areas increases the risk of becoming a NEET up to 1.5 times.

\section{The labour market situation of young people in the EU countries}

There were selected to the analysis a set of labour market indicators, which describe both the activity of young people in the labour market as well as their professional and educational exclusion. The analysis of those measures $^{2}$ (like youth employment rate, youth unemployment rate, youth long-term unemployment rate, early leavers from education and training, NEET rate) prove that the EU countries are diversified in terms of those measures. The EU countries were grouped in clusters following Ward's and k-means methods.

Ward's method is the most popular hierarchical agglomerative method used in the social sciences (Aldenerfer\&Blashfield, 1984). This procedure creates groups which are highly homogeneous by optimizing the minimum variance, or an error sum of squares (ESS), within clusters (Teo, 2014).

The K-means method classifies a given data set through a certain number of clusters (assume k clusters) fixed a priori. The main idea is to define k centroids, one for each cluster (MacQueen, 1967). It is the most useful for forming a small number of clusters from a large number of

\footnotetext{
${ }^{1}$ However, tertiary education does not prevent against becoming a NEET. In the EU, $10 \%$ of young people with such an education have become a NEET. That share is lower for Austria, Denmark, Germany, the Netherlands, Sweden and the UK (it reaches less than 6\%). At the same time, it is twice the EU average in Estonia and Italy - 20\% (Eurofound, 2015).

2 Beside the indicator of early leavers from education and training, which refers to persons aged 18 to 24, the rest of analysed indicators concern people aged 15 - 29.
} 
observations. It requires variables that are continuous with no outliers. In the below analysis there were selected the following 13 variables - Figure 2 and Figure 4 (v1 - early leavers from education and training, v2 - youth employment rate (total), v3 - youth employment rate (female), v4 - youth employment rate (male), v5 - youth unemployment rate (total), v6 - youth unemployment rate (female), v7 - youth unemployment rate (male), v8 youth long-term unemployment rate (total), v9 - youth long-term unemployment rate (female), v10 - youth long-term unemployment rate (male), v11 - NEET rate (total), v12 - NEET rate (female), v13 - NEET rate (male)).

In 2006 both clustering methods grouped the EU countries in three clusters - Figure 1 and Figure 2. Analysing the cluster participants, it can be noted that they are comparable in the groups selected by Ward's method and the k-means method. Cluster 1 consisted of: Poland, Croatia, Slovakia, Greece, Bulgaria, Italy, and Romania. Cluster 2 created by Ward's method gathered Belgium, France, Germany, the Czech Republic, Slovenia, Hungary, Cyprus, Latvia, Estonia, Luxemburg, Lithuania, Spain, Malta, Portugal, at the same time Cluster 2 formed by the k-means method additionally contained Finland and Sweden. Cluster 3 created by Ward's method included Austria, Ireland, the United Kingdom, Denmark, the Netherlands, Finland and Sweden (following the k-means method, the last two countries were not included in Cluster 3, as they joined Cluster 2).

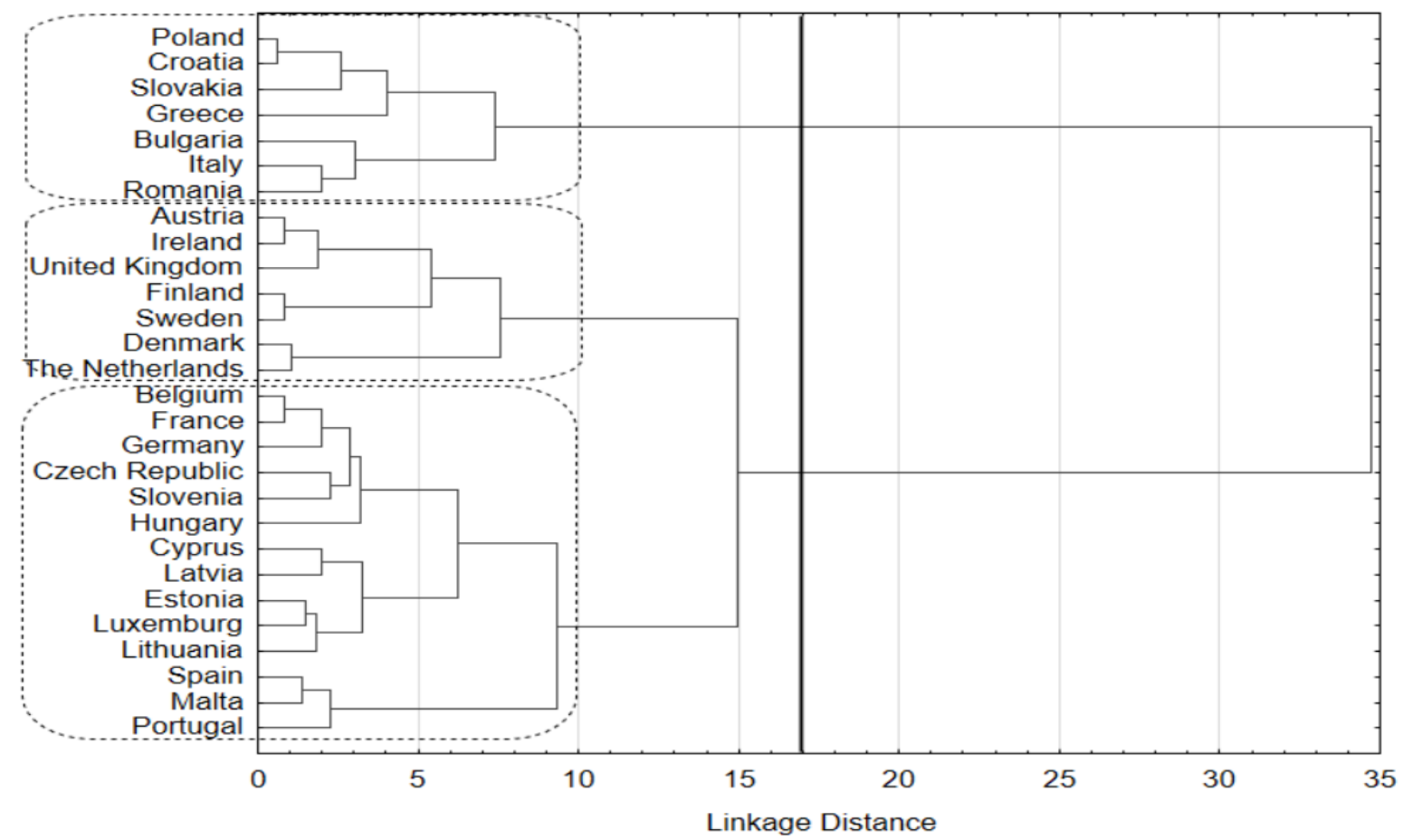

Figure 1. Tree clustering of the European Union countries with respect to selected young people's labour market indicators in 2006 (source: author's calculation based on Eurostat data) 
The $\mathrm{K}$ - means method allows for profiling the clusters in terms of selected variables. In 2006, the countries grouped in Cluster 1 represented the worst situation of young people, as it was characterised by low youth employment rates, high unemployment rates (including long-term unemployment) as well as significant NEET rates. In that period, the best situation of young people was among countries gathered in Cluster 3 Austria, Ireland, the United Kingdom, Denmark, the Netherlands. Cluster 2 represented the average level of the selected indicators.

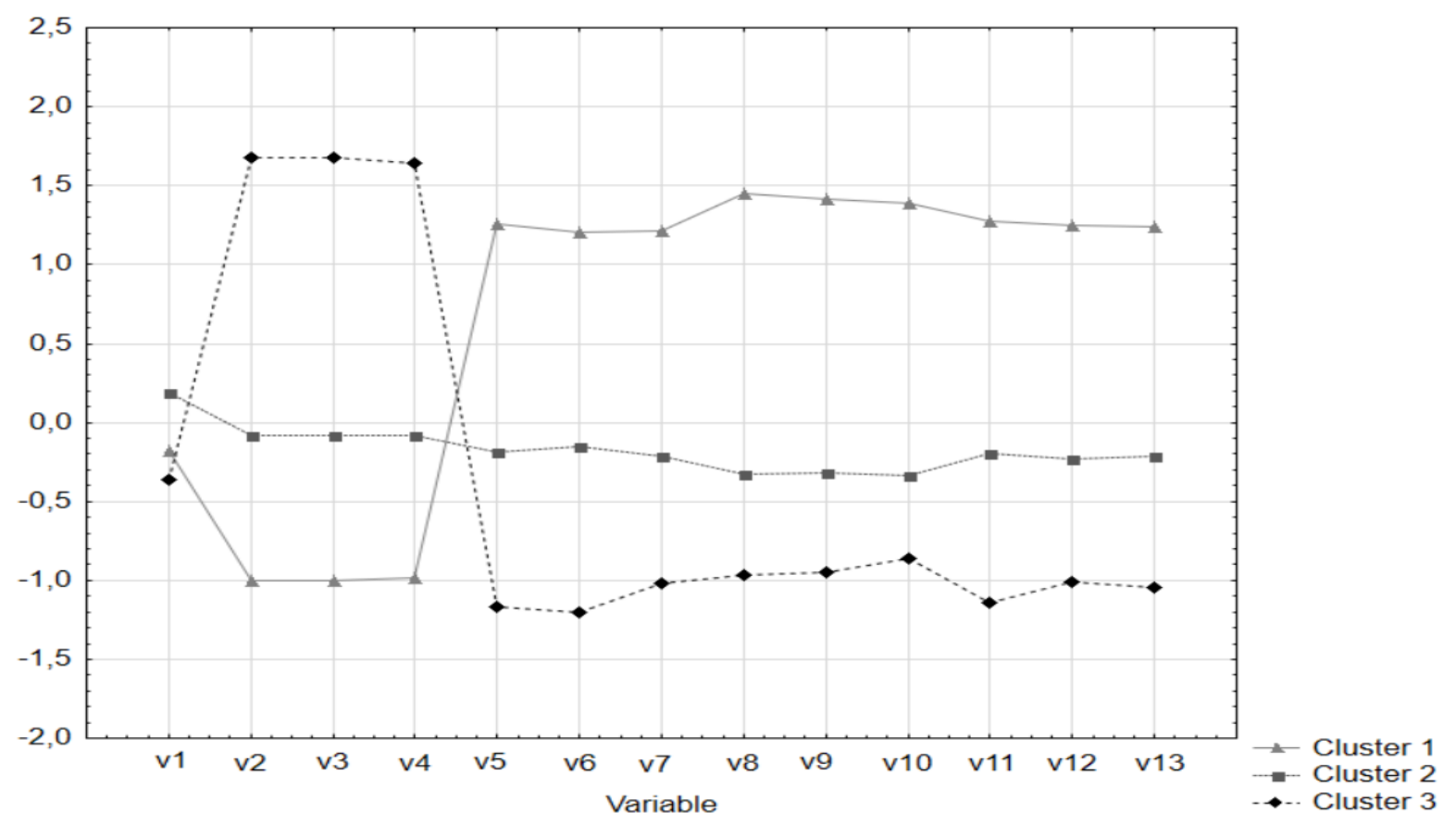

Figure 2. K-means clustering of the European Union countries with respect to selected young people's labour market indicators in 2006 (source: author's calculation based on Eurostat data)

In 2014, after the influence of the crisis effects on the labour market, there were changed the countries included in the selected three clusters. Cluster 1, with the worst young people's indicators, was left by Poland, Slovakia, Romania and Bulgaria and joined by Spain. Cluster 2, representing the average level of the selected indicators, was joined by Poland, Slovakia, Romania and Bulgaria, Ireland (which situation worsened in comparison with 2006). Cluster 2 was left by Spain (moved to Cluster 1), Germany, Latvia, Estonia, Luxemburg, Malta, Finland and Sweden (moved to Cluster 3). 


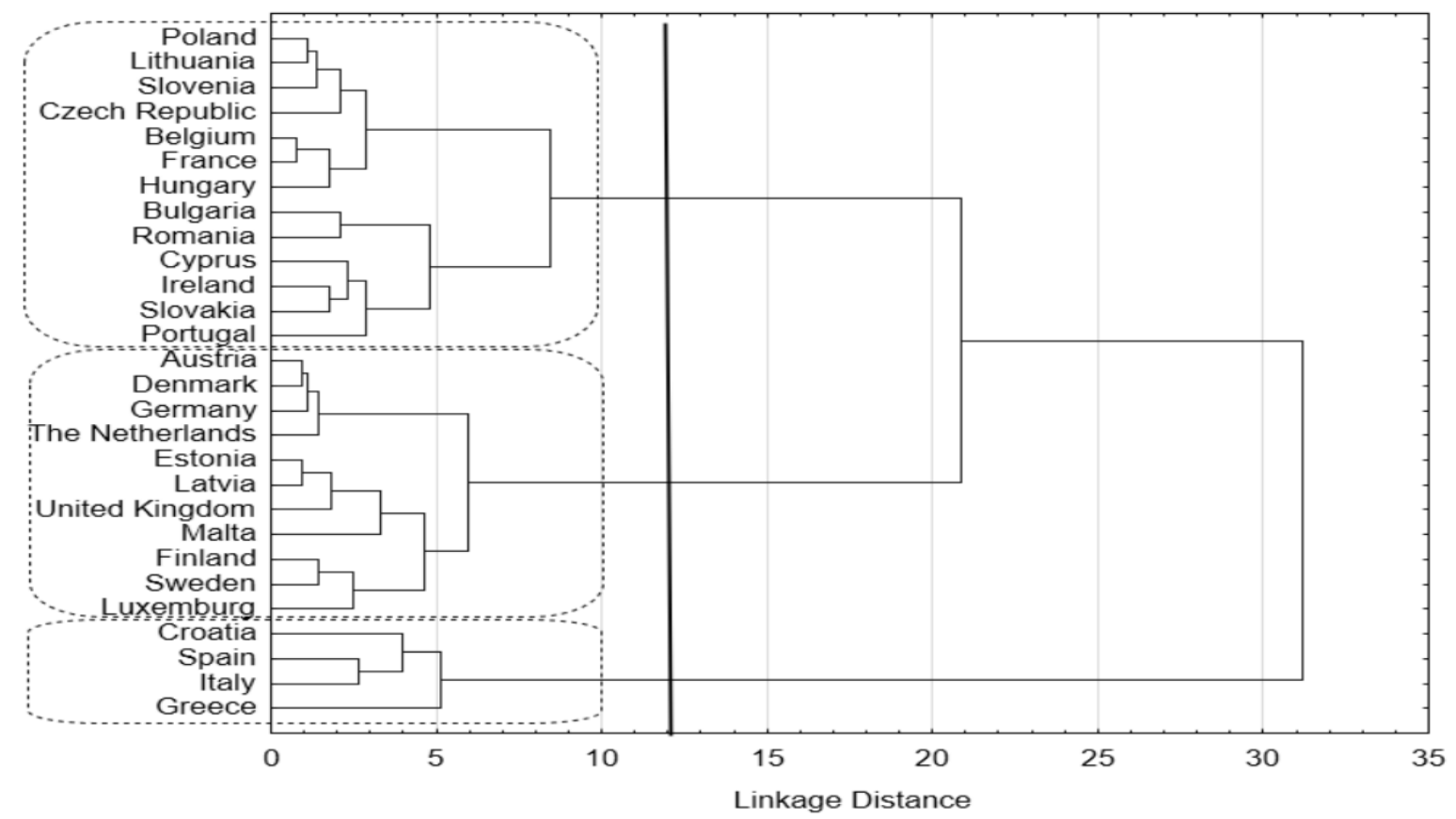

Figure 3. Tree clustering of the European Union countries with respect to selected young people's labour market indicators in 2014 (source: author's calculation based on Eurostat data)

Following k-method clustering, in 2014, the best young people's indicators were in Austria, the Czech Republic ${ }^{3}$, Denmark, Estonia, Finland, the Netherlands, Luxemburg, Latvia, Malta, Germany, Sweden, the United Kingdom (Cluster 3 ). The worst measures were in Croatia, Spain, Italy and Greece.

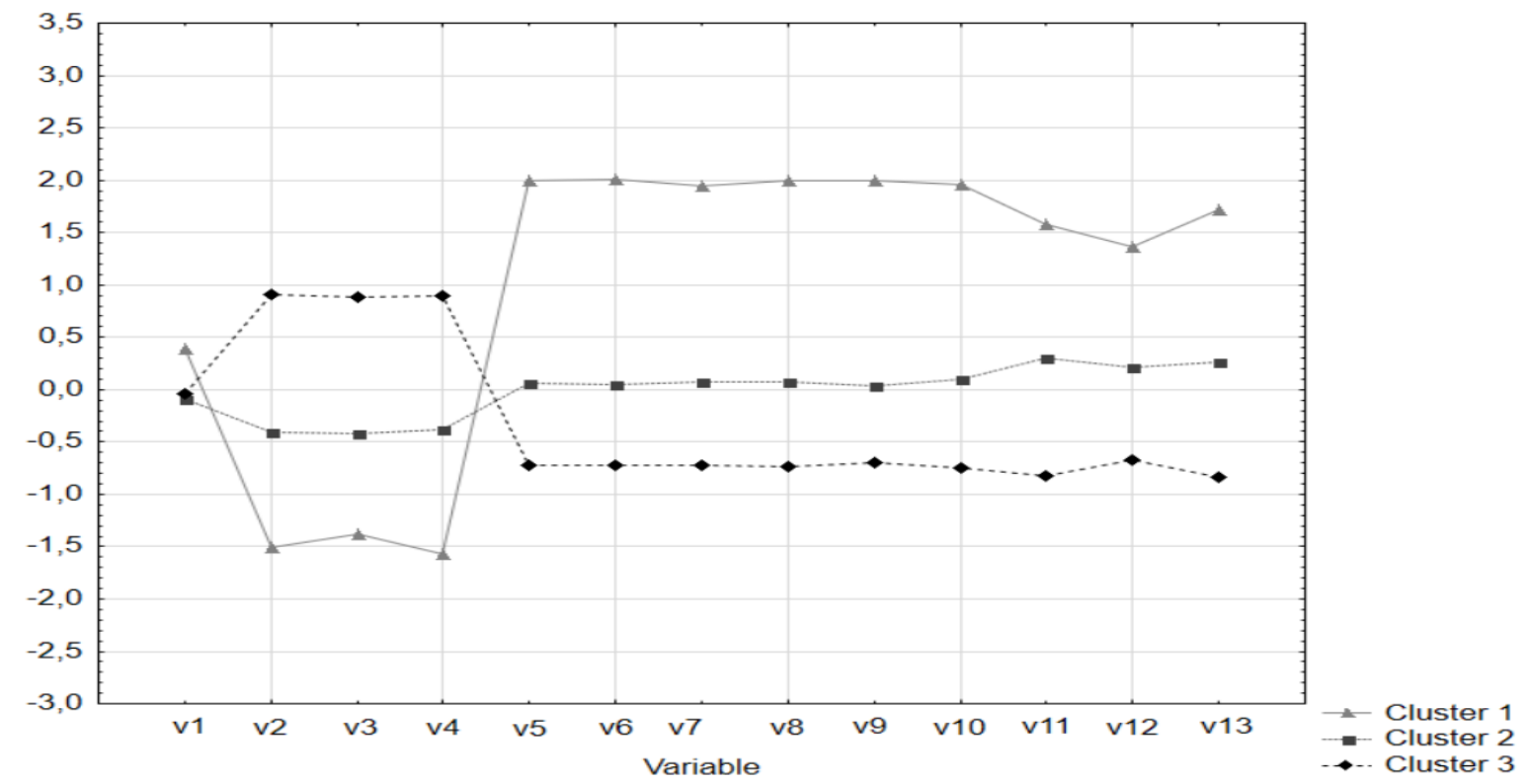

Figure 4. K-means clustering of the European Union countries with respect to selected young people's labour market indicators in 2014 (source: author's calculation based on Eurostat data)

\footnotetext{
3 That country in Ward's method was classified in the cluster 2.
} 


\section{The EU policy aimed at young people}

The EU's overarching Europe 2020 growth strategy highlights young people in one of its five headline targets: aiming to cut early school leaving to no more than $10 \%$ of the student population, and to boost the number of youngsters graduating from university or further education.

To implement the strategy, the European Commission has set out seven flagship initiatives. One of these, entitled Youth on the Move, aims to improve education and training and make it more relevant to young people's needs, encourage them to take advantage of the EU grants and opportunities to study or train in another EU member state, and ultimately help them to find employment.

The EU Member States have also tried a number of measures to prevent young people of becoming a NEET and to reintegrate those who are NEETs.

Maguire and Rennison (2005) consider that the measures adopted by governmental bodies subsidising youths to remain in the educational system have a positive impact on diminishing the numbers of youths going through the NEET state.

Vocational Education and Training (VET) systems can help to reduce early school leaving by offering an alternative to general education. Successful approaches often combine work experience with more theoretic and school-based teaching and strongly involve business. Also better guidance and better targeted support of VET students can help to reduce early school leaving.

Moreover, it is essential to engage employers and their representatives in construction the measures that focus on fostering their beneficiaries' employability (Eurofound 2015).

Because of heterogeneity of NEET's group (Furlong, 2006), the policy directed toward that group of young people should be able to identify the distinct characteristics and needs of the various sub-groups (Elder, 2015).

The following actions are proposed for unemployed non-students: active labour market policies to encourage hiring of young persons ${ }^{4}$, sectoral and monetary policies to encourage job growth; social protection of the unemployed; training programmes for the unemployed; aligning the education system with labour demand5; entrepreneurship training and incubation; employment services.

\footnotetext{
${ }^{4}$ Those actions seem to be effective in Nordic countries and the Netherlands (all included in cluster 3 in the above analysis).

${ }^{5}$ One of the solutions in that area is dual learning developed in Germany and Austria (belonging to the cluster 3).
} 
Younger bands (15-19, 20-24), who can be less educated face higher unemployment; require re-training programmes; improvements in the education system; encouraging more inclusive education, including technical education; apprenticeship and mentoring programmes.

In the case of the upper age band (25-29), there is an issue of graduate unemployment and likely to be structurally unemployed; policies should aim at a mix of policies above (to address unemployment) but with heavy concentration as well on promoting job growth.

Limited job growth in a country can push young people to remain inactive at home or migrate. In such a situation, policies should aim at a mix of policies above (to address unemployment) but with heavy concentration on promoting job growth and social protection to ensure basic needs are met.

If the cultural or discriminatory practices exclude one sex (typically young women) from the labour market, policy should include legal responses to promote an equal opportunity, public awareness campaigns, promotion of entrepreneurship, provision of child-care solutions, widening the occupational spectrum for both sexes and perhaps even subsidizing all female enterprises or branches of enterprises.

In the case of younger bands (15-19), there is a problem of ESL. The policy mix in this regards should be geared toward improved investment in the education system with universal access.

\section{Conclusions}

Young people situation in the European Union labour market is worse than for the average population. The young people's exclusion concerns not only low employment level and high unemployment but there has also been noticed early school leaving as well as the phenomena of maintaining by people aged 15-29 without employment, education and training.

The conducted analysis of young people indicators proves the substantial heterogeneity of the youth situation in the European Union labour market.

The cluster of countries with the best labour market indicators is currently created by Austria, the Czech Republic, Denmark, Estonia, Finland, the Netherlands, Luxemburg, Latvia, Malta ${ }^{6}$, Germany, Sweden, and the United Kingdom.

In Nordic countries and the Netherlands, it can be connected with the strong position of effective active labour market policy (ALMP) in their

\footnotetext{
${ }^{6}$ The recession in Malta was less severe and its impact on the labour market more moderate. It could influence relative improvement of young people situation (Central Bank of Malta, 2013).
} 
flexicurity models (Rollnik-Sadowska, 2013). Even though there is high employment elasticity, ALMP enables efficient return to the labour market.

Austria and Germany followed by the Czech Republic, Latvia or Estonia have implemented education policies adjusted to labour demand needs (in Germany based on the large extend on dual learning). Moreover, industries in Germany are characterised by high labour demand, which means a significant number of vacancies (which also influence neighbouring Austria and the Czech Republic).

The surplus labour demand is the domain of Luxembourg, where the excess job openings have to be filled with outside job seekers.

The United Kingdom represents strong workfare state orientation focused on the professional activation (Rollnik-Sadowska, 2015).

At the same time, the worst situation of young people is in the countries (Spain, Italy and Greece) which suffer from the results of crisis influencing their labour markets. It is also unfavourable in the new EU Member State - Croatia.

The EU policy aimed at solving young people problems should consider good patterns implemented in the countries with the stable situation in labour market of that age group. That favourable situation is connected both with the structural reforms of social policy as well as the efficient labour market and educational policies.

\section{References}

1. ALDENERFER, M. S., BLASHFIELD, R. K. (1984). Cluster analysis, Sage University Paper series on Quantitative Applications in Social Sciences, series no. 07-044, Beverly Hills, California: Sage Publications.

2. BĂLAN, M. (2015). Methods to Estimate the Structure and Size of the "Neet" Youth, Procedia Economics and Finance, Volume 32. p. 119-124.

3. BYNNER, J., PARSONS, S. (2002). Social Exclusion and the Transition from School to Work: The Case of Young People Not in Education, Employment, or Training (NEET), Journal of Vocational Behaviour, 60(2). p. 289- 309.

4. CARCILLO, S., FERNÁNDEZ, R., KÖNIGS, S., MINEA, A. (2015). NEET Youth in the Aftermath of the Crisis, Challenges and policies, OECD, France 2015. DOI 10.1787/5js6363503f6-en p. 1-108.

5. CENTRAL BANK OF MALTA (2013). Labour market resilience in Malta. Report published in the Quarterly Review 2013:1. p. 2-6.

6. ELDER, S. (2015). What does NEETs mean and why is the concept so easily misinterpreted? Technical Brief No. 1, Youth Employment Programme, Employment Policy Department, International Labour Office, The MasterCard Foundation. p. 1-16.

7. EUROFOUND (2015). Youth unemployment in Europe. NEETs - young people not in employment, education or training. Retrieved March 30, 2016, from http://www.eurofound.europa.eu/printpdf/young-people-and-neets-1 
8. EUROSTAT, Being young in Europe today - demographic trends, Retrieved March 19, 2016, from http://ec.europa.eu/eurostat/statistics-explained/index. php/Being_young_in_Europe_today_-_demographic_trends

9. EUROPEAN COMMISSION, Europe 2020 target: Early leavers from education and training. Retrieved March 25, 2016 http://ec.europa.eu/europe2020/ pdf/themes/29_early_school_leaving.pdf

10. FURLONG, A. (2006). Not a very NEET solution: representing problematic labour market transitions among early school-leavers, in Work, Employment and Society, Vol. 20, No. 3, September. p. 553-569.

11. MACQUEEN, J. B. (1967). Some Methods for classification and Analysis of Multivariate Observations, Proceedings of 5-th Berkeley Symposium on Mathematical Statistics and Probability, Berkeley, University of California Press. p. 281-297.

12. MAGUIRE, S., RENNISON, J. (2005). Two Years On: The Destinations of Young People who are Not in Education or Training at 16, Journal of Youth Studies, 8(2). p. 187-202.

13. ROLLNIK-SADOWSKA, E. (2013). Zastosowanie modelu Flexicurity $w$ polityce zatrudnienia Unii Europejskiej (ze szczególnym uwzględnieniem Polski), Optimum - Studia Ekonomiczne nr 4. p. 37-46.

14. ROLLNIK-SADOWSKA, E. (2015). Transformation of European labour market policy models- exemplified by Denmark, Germany and the United Kingdom, Optimum - Studia Ekonomiczne nr 5. p. 38-51.

15. TEO, T. (ed.) (2014). Handbook of Quantitative Methods for Educational Research, Springer Science \& Business Media, 07.02.2014 - 404. p. 110.

16. THE EUROPEAN ECONOMIC AND SOCIAL COMMITTEE (2011). Europe 2020 and employment for young people, Retrieved March 19, 2016, from http://www.eesc.europa.eu/resources/docs/eesc_11_96_en.pdf 


\title{
JAUNIEŠI EIROPAS SAVIENĪBAS DARBA TIRGŪ
}

\author{
Ewa Rollnik-Sadowska
}

Belostokas Tehnologiju Universitāte, docente

\section{Kopsavilkums}

Eiropas iedzīvotāju novecošanās laikmetā ir svarīgi parūpēties par cilvēkresursiem dažādās dzīves sfērās. Īpaši ir svarīgs jauniešu potenciāls, jo to ekonomiskā darbība rada pamatu, lai saglabātu Eiropas labklājības valsts modeli. Taču jauniešu stāvoklis darba tirgū ir smags. Vēl jo vairāk, tās parādības, kuras piesaistīja pastiprinātu uzmanību, ir aktuālas jauniešiem bez darba, izglītības vai nemācās (JBDIN). Mikrolīmenī, JBDIN resursi ir kaitīgi, jo Eiropas mājsaimniecības kḷūst nabadzīgākas, kā arī tas ir nelabvēlīgi visai tautsaimniecībai, jo netiek izmantoti visi cilvēkresursi. Raksta mērḳis ir salīdzināt jauniešu stāvokli Eiropas Savienības darba tirgū.

Raksts tika balstīts uz literatūras izpēti un jauniešu (15-29 gadu vecumā) ekonomisko rādītāju analīzi. Rādītāju analīze tika veikta, izmantojot klasteru analīzes metodi (Varda metodi un k-vidējo vērtību metodi). Dati tika iegūti no Eurostat datubāzēm. Izvēlētie rādītāji raksturo jauniešu stāvokli darba tirgū ES valstīs un tie tika izvēlēti diviem gadiem - 2006. un 2014. gadam.

Varda un k-vidējo vērtību metodes lāava iedalīt ES valstis trīs grupās. Izrādījās, ka grupu iedalījums 2006. gadā pilnīgi atšksīrās no iedalījuma 2014. gadā, ko galvenokārt noteica krīzes ietekme uz darba tirgu, kā arī îstenoto reformu virzieni. Bez tam, kvidējo vērtību metode l̦āva salīdzināt izvēlētās grupas uz atlasīto rādītāju pamata un noteikt valstis, kurās jauniešiem ir vislabākais un vissliktākais stāvoklis darba tirgū.

Atslēgas vārdi: jaunieši, darba tirgus rādītāji, darba tirgus politika, izglītības politika, jauniešiem bez darba, izglītības vai nemācās, Eiropas Savienība, Varda metode, k-vidējo vērtību metode. 